\title{
USING MULTI-CRITERIA ANALYSIS FOR THE STUDY OF HUMAN IMPACT ON AGRO-FORESTRY-PASTORAL ECOSYSTEM IN THE REGION OF KHENCHELA (ALGERIA)
}

\author{
A. Bouzekri ${ }^{\text {a }}, \mathrm{H}$. Benmessaoud ${ }^{\mathrm{b}, *}$
}

\author{
${ }^{a}$ University El Hadj Lakhdar -Batna- Algeria. Email - hafid123bouzekri@gmail.com \\ ${ }^{\mathrm{b}}$ Laboratory, Natural Risks and Planning, Faculty of Science - ha123_ma123@yahoo.fr
}

KEY WORDS: Multi-criteria analysis, human impacts, ecosystem, Khenchela.

\begin{abstract}
:
The objective of this work is to study and analyze the human impact on agro-forestry-pastoral ecosystem of Khenchela region through the application of multi-criteria analysis methods to integrate geographic information systems, our methodology is based on a weighted linear combination of information on four criteria chosen in our analysis representative in the vicinity of variables in relation to roads, urban areas, water resources and agricultural space, the results shows the effect of urbanization and socio-economic activity on the degradation of the physical environment and found that $32 \%$ of the total area are very sensitive to human impact.
\end{abstract}

\section{INTRODUCTION}

The eastern Aures is part of the arid and semi arid Mediterranean, and consist of a unique ecosystem, they are now experiencing a strong trend of degradation that results in the reduction of the biological potential and disruption of the ecological balance, Khenchela is an agro-forestry-pastoral vocation region experienced a strong population growth coupled with uncontrolled spatial development of the territory. causes an advanced state of degradation, due to anthropogenic actions: deforestation, overgrazing, overexploitation of groundwater and urbanization.

Human intervention is the only responsible for the degradation of ecosystems due to mismanagement of fragile land of steppe environment, and development patterns of inadequate pastures led to the appearance of original deserts anthropogenic whose evolution will be difficult to reverse.

This work has given the main objective to study and analyze the impact of human activities and socioeconomic that have a direct or indirect link to the degradation of agro-forestry-pastoral ecosystems, we have applied in this study the hierarchical multi-criteria analysis approach integrated with geographic information systems (GIS) for weighting and aggregating stakeholder criteria in the degradation of these ecosystems

\section{PRESENTATION OF THE STUDY}

The study area is located in the east of Algeria, South East Constantine and the foothills of Mount Aures between $34^{\circ} 06^{\prime} 36$ " $35^{\circ} 41^{\prime} 21$ " north latitude and between $06^{\circ} 34^{\prime} 12$ " $07^{\circ} 35^{\prime} 56^{\prime}$ East longitude, it covers a total area of neighboring 144,231.75 hectares, with a population of 399,200 inhabitants. It consists of 21 town, it rises to $2326 \mathrm{~m}$ Ras Kulthum, is the highest of northern Algeria, it is characterized by high gradients.

By its geographical position, the wilaya of Khenchela that is not only limited; Wilaya five, whose ties remain very strong in all areas of economic and social activity, it is also a hyphen, no less significant between the North / East and South of the country. It is thus, at the gateway of the great cities of the south, not far from the northern metropolitan cities. It is characterized by its agro-forestry-pastoral or agricultural area represents $22 \%$ forests, $12 \%$ and steppe represents $49 \%$ of the total area of the study area. 


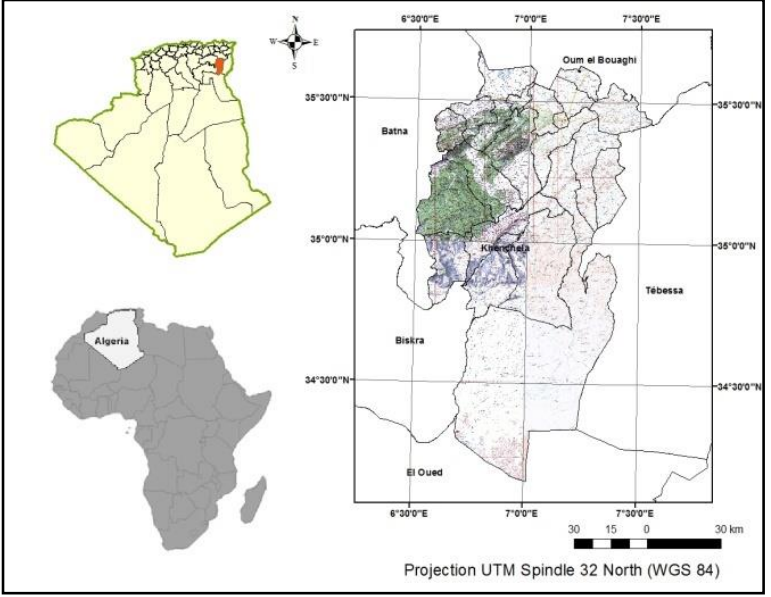

Figure 1. Geographic situation of study region.

\section{METHODOLOGIE}

Our approach is based on the integration of geographic information systems (GIS) and methods of multi-criteria analysis developed by Saaty (Analytical Hierarchy Process AHP) to study the impact of anthropogenic activities on the study area for this integration we pursued three main stages: development of criteria, criteria weighting and aggregation criteria.

\subsection{Development of criteria}

GIS offers the functions for acquiring data in digital form, validation, management, processing and spatial analysis, thematic and multi-thematic georeferenced data, the first step AHP process is to break down the decision problem that consists of the most important element of the decision problem, in this stage the complex problem of the human impact study on the ecosystem of the wilaya of Khenchela is broken down into a hierarchy of decision criteria, in the case of this study four criteria chosen in our analysis representative in the vicinity of variables in relation to roads, urban areas, water resources and agricultural villages .these criteria were extracted from the map data with spatial reference and are measured using the spatial analysis capabilities of GIS.

\subsubsection{Criterion of proximity to urban areas}

Urbanization is one of the first criteria anthropogenic causes of ecosystem disturbances, and poses a serious threat to biodiversity.

The growth of urban areas is due to the increasing migration of rural population to cities to enjoy the benefits that urban areas offer such as education, health care and post work. this growth puts in place permanent anthropogenic structures that cause profound changes to the landscape and soil use changes through the conversion of rural areas to urban planning purposes. The criterion of proximity card masterpiece around the different places of the province of Khenchela were mapping from Landsat satellite image processing 2015, by thresholding technique application on the processed image to automatically extract the limits of agglomerated areas and then we applied GIS software DISTANCE depending on the limits of urban areas

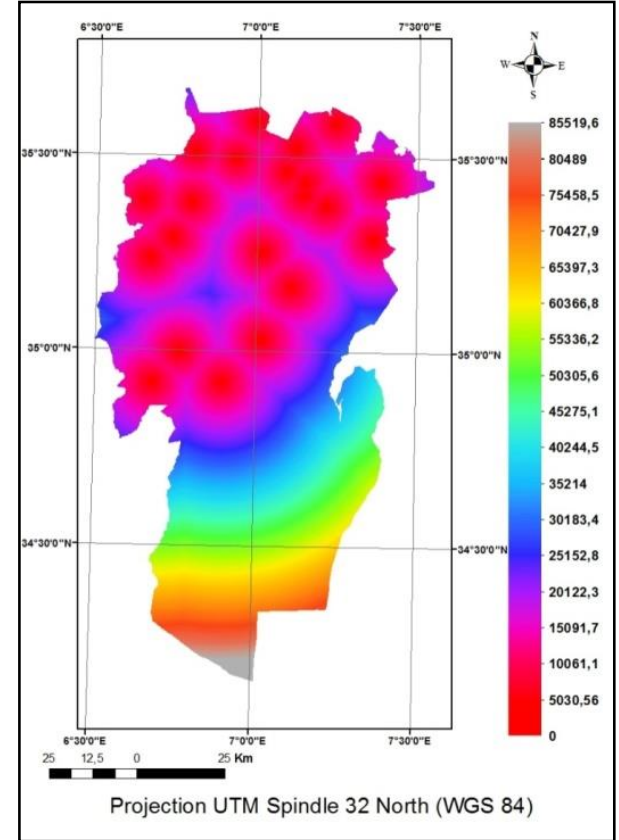

Figure 2 : Map of the distances (in meters) compared to urban areas.

\subsubsection{Proximity criterion Road Network}

Road infrastructures have significant impacts on ecosystems amplified by the movement of vehicles, the condensation of the road network plays an important role in the breaking of natural environments by roads that affects their continuity, it hinders the movement of cash and reduces the exchanges between ecosystems.

The proximity card to road networks was developed by the technique of spatial analysis, this technique applied on the linear vector data of national highways, communal and wilaya and the main runway, which obtained using scanning four topographic maps at the scale of 1:200,000 of the old division of 1957 and the use of new cutting cards of 2004 to update the mapping of the road network.

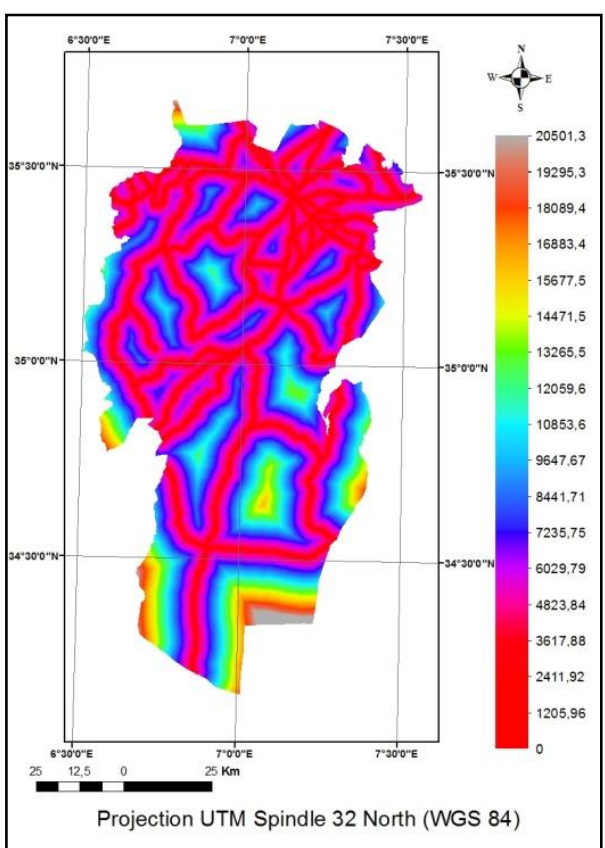

Figure 3: Map of the distances (in meters) from the road network. 


\subsubsection{Proximity criterion of water resources:}

The proximity to water resources is an important parameter to consider in the study of the impact of human actions on the study area, the availability of water resources is one of the key parameters for agropastoral activities and Installation of the population. The main water resources in the study area are: dams and retained water, wells and boreholes, according to the management of agricultural services of the wilaya of Khenchela water resources are localized to the full of Remila and south of the town of Babar, a point vector database was performed using the geographical coordinates of water resources that has been converted to raster data to perform map of nearby water resources.

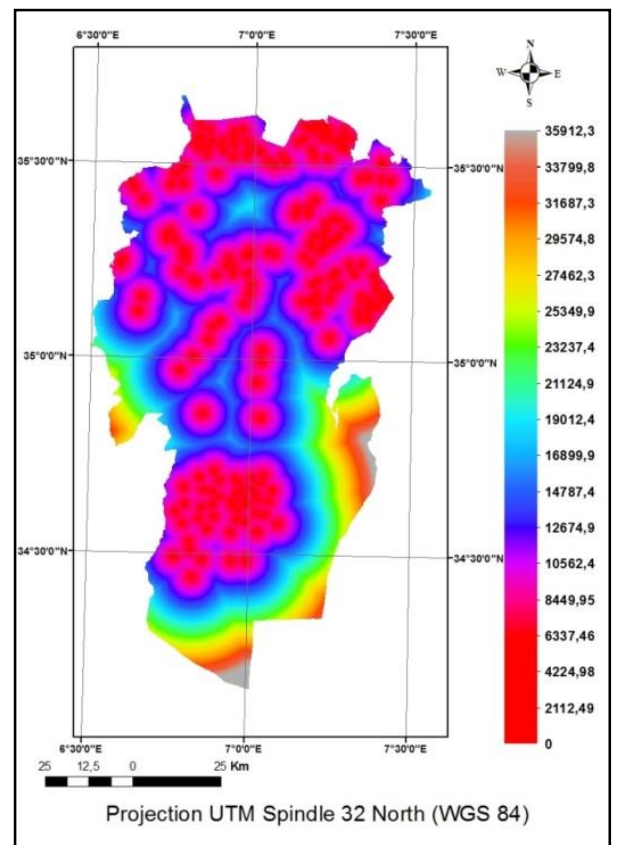

Figure 4: Map of the distances (in meters) relative to the water resources.

\subsubsection{Criteria nearby agricultural villages}

The nearby farming villages is a criterion of great importance in land degradation, most modes of agriculture through the work of clearing and deforestation leads to a significant reduction in plant cover with loss of bedding and humus, which promotes triggering the risk of erosion and desertification as the case of the South study area characterized by a fragile ecosystem and intensive agriculture.

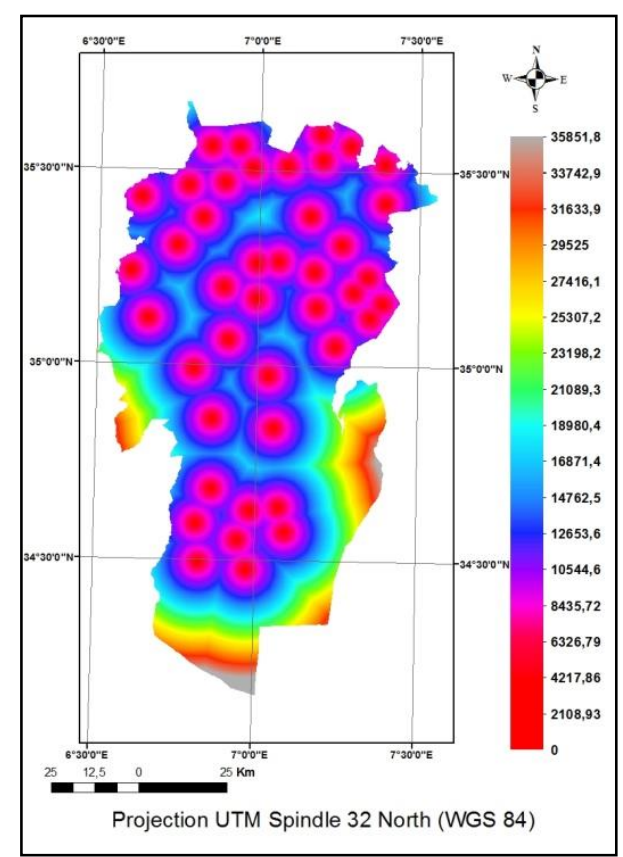

Figure 5: Map of the distances (in meters) relative to the agricultural village.

\subsection{Weighting of criteria}

Before developing the aggregation of different criteria of human activities affecting the ecosystem of the study area, we followed the hierarchical multi-criteria analysis method (Analytical Hierarchy Process AHP) developed by Saaty, it allows produce standardized weights whose sum is equal to "1", the method is based on a series of pairwise comparisons of these criteria from the construction of a square matrix taking into account the relative importance a criterion relative to another, for the establishment of such measures using Saaty scale (table 1) which takes values from 1 to 9 these values from 1 to 9 allow to fill a matrix for pairwise comparison (Table 2), facilitating the calculation of the eigenvector of each criterion indicating the weighting factor of these criteria.

\begin{tabular}{|l|l|}
\hline $\begin{array}{l}\text { Expression of a criterion with } \\
\text { respect to another }\end{array}$ & $\begin{array}{l}\text { Degrees of } \\
\text { importance }\end{array}$ \\
\hline $\begin{array}{l}\text { equal importance of both } \\
\text { criteria }\end{array}$ & 1 \\
\hline $\begin{array}{l}\text { A criterion is a bit more } \\
\text { important than the other }\end{array}$ & 3 \\
\hline $\begin{array}{l}\text { A criterion is more important } \\
\text { than the other }\end{array}$ & 5 \\
\hline $\begin{array}{l}\text { A criterion is much more } \\
\text { important than the other }\end{array}$ & 7 \\
\hline $\begin{array}{l}\text { A criterion is absolutely more } \\
\text { important than the other }\end{array}$ & 9 \\
\hline $\begin{array}{l}\text { A criterion is a little less } \\
\text { important than the other }\end{array}$ & $1 / 3$ \\
\hline $\begin{array}{l}\text { A criterion is less important } \\
\text { than the other }\end{array}$ & $1 / 5$ \\
\hline $\begin{array}{l}\text { A criterion is far less important } \\
\text { than the other }\end{array}$ & $1 / 7$ \\
\hline $\begin{array}{l}\text { A criterion is absolutely less } \\
\text { important than the other }\end{array}$ & $1 / 9$ \\
\hline
\end{tabular}

Table 1. Digital Scale Saaty pairwise comparison criteria. 
The determination of weight for each test is the pairwise comparison of the relative importance established from the Saaty digital scale, which resulted in the configuration of the matrix $\mathrm{M}$ mutual decision, for example in the decision matrix for the criterion of proximity to urban areas is more important than the water resources of proximity criterion and a little more important than the criterion of proximity to road networks in the impact of these criteria on the ecosystem of the study areas.

\begin{tabular}{|l|c|c|c|c|}
\hline & $\begin{array}{c}\text { Urban } \\
\text { zone }\end{array}$ & $\begin{array}{c}\text { Road } \\
\text { Network }\end{array}$ & $\begin{array}{c}\text { Water } \\
\text { Resources }\end{array}$ & $\begin{array}{c}\text { farming } \\
\text { villages }\end{array}$ \\
\hline urban areas & 1 & 3 & 5 & 5 \\
\hline $\begin{array}{l}\text { road } \\
\text { network }\end{array}$ & $1 / 3$ & 1 & 5 & 5 \\
\hline $\begin{array}{l}\text { Water } \\
\text { resources }\end{array}$ & $1 / 5$ & $1 / 5$ & 1 & 1 \\
\hline $\begin{array}{l}\text { agricultural } \\
\text { villages }\end{array}$ & $1 / 5$ & $1 / 5$ & 1 & 1 \\
\hline
\end{tabular}

Table 2. Matrix weighting pairwise criteria.

For estimating the weighting coefficient requires the calculation of the eigenvector $(\mathrm{Vp})$ of the comparison matrix in pairs, the values of these eigenvectors $(\mathrm{Vp})$ are determined by calculating their geometric mean by cork for each criterion and the weighting coefficient for each criterion is deduced by standardizing the eigenvector by dividing each eigenvector by their sum and provided that the sum of the weighting coefficients must be equal to 1 .

\begin{tabular}{|l|l|}
\hline Criterion & Poids \\
\hline urban areas & 0,5383 \\
\hline road network & 0,3051 \\
\hline Water resources & 0,0783 \\
\hline agricultural villages & 0,0783 \\
\hline Total & 1 \\
\hline
\end{tabular}

Table 3. Weight values for the different criteria.

\subsection{Aggregation criteria:}

In the final step, the decision criteria are aggregated by the method of the weighted sum based on their weights, this aggregation is to multiply each standardized test layer by its coefficient of respective weighting, which allows us to map the deteriorating study zone.

\section{RESULTS AND DISCUSSION}

After aggregation of weighted criteria, we obtained a decision card of the impact of human activities on agroforestry-pastoral ecosystem of the wilaya of Khenchela, and allowed us to map the most exposed to human intervention areas.

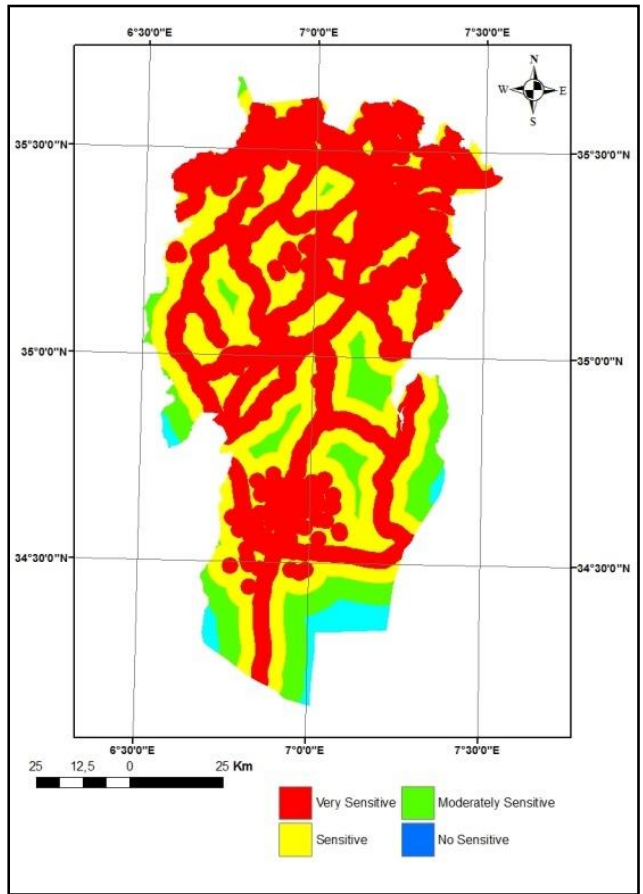

Figure 6. Map of sensitivity of an ecosystem agroforestry-pastoral vis-à-vis the human impact.

\begin{tabular}{|l|c|c|}
\hline $\begin{array}{l}\text { Sensitivity } \\
\text { towards } \\
\text { human impact }\end{array}$ & $\begin{array}{l}\text { The area in } \\
\text { hectares }\end{array}$ & $\begin{array}{l}\text { The area } \\
\text { in\% }\end{array}$ \\
\hline $\begin{array}{l}\text { no sensitive } \\
\text { areas }\end{array}$ & 11711,62 & 8,12 \\
\hline $\begin{array}{l}\text { moderately } \\
\text { sensitive areas }\end{array}$ & 31096,36 & 21,56 \\
\hline sensitive areas & 53985,94 & 37,43 \\
\hline $\begin{array}{l}\text { very sensitive } \\
\text { areas }\end{array}$ & 47437,57 & 32,89 \\
\hline \begin{tabular}{l} 
Total \\
\hline
\end{tabular} & 144231,75 & 100 \\
\hline
\end{tabular}

Table 4. Area and percentage of the sensitivity classes to human impact.

Examining the map of anthropogenic pressure and the different criteria maps and statistical data in Table 4 show that the sensitivity of the study area to the human impact from non-sensitive areas to very sensitive areas.

very sensitive areas: these very sensitive areas are the most vulnerable to ecosystem degradation by the influence of human intervention areas, these areas are around the masterpiece places of the wilaya of Khenchela and communications channels, especially in the Nord party distinguished by many of the chief towns and cities that colonize the alfa grass Nemamcha of the region and the forest Esalhin Hamam, the estimate of the proportion of these very sensitive to human activities areas compared to the total area the study area is of $32.89 \%$, an area of $47,437.57$ hectares, these zones characterized by the degradation of ecosystem to the irreversibility of the land and the radical change in land use. 
Hotspots: sensitive areas account for much of the study area, they occupy $53,985.94$ hectares or $37.43 \%$ of total area and is mainly localized in the full valleys that distinguish by agriculture and pastoralism around water resources and fertile soils, the ecosystem corresponds to these areas distinguished by the degradation of vegetation due to land clearing to create new farmland. moderately sensitive areas: These areas corresponding to areas threatened potentially the impact of human activities on ecosystem degradation, these areas have an area of $31,096.36$ hectares or $21.56 \%$ of the total area of the study area, and well illustrated on the tops of mountains and south of the town of Babar.

Areas not sensitive: these areas corresponding to the nonthreatened areas by human intervention, we considered that these areas is considered unfavorable to any area of population and agricultural activity as is found on the higher slopes, the old dunes and chott Melghir.

\section{CONCLUSION}

GIS and methods of hierarchical multi-criteria analysis were used in this study, we took into account the criteria of proximity to road networks, urban areas, water resources and agricultural areas, these four criteria we allows to study and map the human influences on the Khenchela region through the development works and the exploitation of natural resources. According to the final map that shows the sensitivity of the study area is to screw the human interventions, we find that $32 \%$ of the total area are very sensitive and are located around major cities and national roads, these results allows to highlight the extent of human pressure on the ecosystem of the Khenchela region.

\section{REFERENCES}

Bensaid, A., Barki, M., Talbi, O., Benhanifia, K. et Mendas, A. (2007). L'analyse multicritère comme un outil d'aide à la décision pour la localisation spatiale des zones à forte pression anthropique : le cas de département de Naàma en Algérie. Revue de télédétection, 7. (1-2-34), p359-371.

Boroushaki, S., Malczewski, J., 2008. Implementing an Extension of the Analytical Hierarchy Process Using Ordered Weighted Averaging Operators with Fuzzy Quantifiers in ArcGIS. Computers \& Geosciences. 34(4), 399-410.

Boroushaki, S., Malczewski, J., 2010. Measuring Consensus for Collaborative Decision-making. A GISbased approach. Computers, Environment and Urban Systems. 34(4), 322-332.

Bouzekri,A., Benmassaoud, H., 2014. Study and diachronic analysis of changes of ground occupation in area of oriental Aures Algeria. Analele Universitatti din Oradea - Seria Geografie, Year XXIV,no2.

Benmassaoud, H., Kalla, M., Abdesselam, S., Bensaid, A., 2011.Utilisation d'un SIG pour l'étude de l'impact socio-économique sur le milieu Physique dans l'Est des
Aurès (Algérie), European Journal of Scientific Research, vol.53, No.4, pp.637-652

Conchita, M., Kêdowide, G. 2010. Modélisation géomantique par évaluation multicritère pour la prospection des sites d'agriculture urbaine à Ouagadougou. Vertigo.10(2).

Saaty, T.L., 1977. A scaling method for priorities in hierarchical structures. Journal of mathematical Psychology, No 15,pp. 234-281 